\title{
Pythium Root Rot of Sugarcane in Puerto Rico. I. Pathogenicity and Identification ${ }^{1}$
}

\author{
Lii-Jang Liu $^{2}$ \\ ABSTRACT
}

\begin{abstract}
Pythium aphanidermatum, a previously unreported species for Puerto Rico, and $\boldsymbol{P}$. deliense were frequently isolated from sugarcane fields in the southern coast of Puerto Rico where symptoms of ratoon stunting disease were also observed. $P$. acanthicum, $P$. butleri, $P$. echinocarpum, $P$. graminicola, $P$. oligandrum and $P$. periplocum were also isolated. The pathogenicity of these Pythium species to sugarcane variety PR 1152 was demonstrated in replicated laboratory and greenhouse tests. P. aphanidermatum alone significantly reduced dry weights of top and root growth of sugarcane variety PR 1085. Reductions in dry weights of top and root growth incited by the combination of $\boldsymbol{P}$. deliense and $\boldsymbol{P}$. aphanidermatum were the same as those caused by $P$. aphanidermatum alone. However, the reductions in dry weights of top by inoculation of sugarcane with both $P$. aphanidermatum and the ratoon stunting disease causal agent were greater than those caused by inoculation with either one alone.
\end{abstract}

\section{INTRODUCTION}

Root diseases caused by pythiaceous and non-pythiaceous fungi have long been considered among the most serious diseases affecting sugarcane in Puerto Rico (1). Matz in 1920 (6) isolated a Pythium sp. from sugarcane roots in Puerto Rico and proved its pathogenicity, but failed to identify the species. Koike in 1969 (2) isolated several species of Pythium from sugarcane roots and soil in Puerto Rico and reported on the pathogenicity of $P$. graminicola to commercial variety PR 980. Pathogenicity of $P$. tardicrescens to sugarcane has also been reported (3). Recently Liu (5) reported on the pathogenicity of several Pythium species isolated from sugarcane in Puerto Rico.

In the fall of 1974, the locally developed varieties, PR 62-2314, PR 61632, PR 1152, PR 64-1791, PR 65-625, M 336 and B 49119 were severely affected by a root disease complex in certain fields of Central Mercedita on the southern coast of the Island. Symptoms of ratoon stunting disease were also observed. More than 50\% of the Pythium isolates from that area were identified as $P$. aphanidermatum or $P$. deliense. This paper reports on the identification and pathogenicity of Pythium spp. isolated from sugarcane in Puerto Rico, and on the interaction between $P$. aphanidermatum and the ratoon stunting disease agent (RSD).

'Manuscript submitted to Editorial Board February 8, 1979.

${ }^{2}$ Phytopathologist, Department of Crop Protection, College of Agricultural Science, Agricultural Experiment Station, Mayagüez Campus, University of Puerto Rico, Río Piedras, P. R. 


\section{MATERLALS AND METHODS}

\section{ISOLATION AND IDENTIFICATION}

Roots of sugarcane showing reddish brown lesions resembling Pythium root rot were collected from 25 fields at Central Mercedita, Fortuna, Lajas, Central Plata, Fajardo and Humacao in the southern, central and eastern parts of Puerto Rico, respectively (table 1). A selective cultural medium consisting of corn meal agar, $18 \mathrm{~g}$; pimaricin, $2 \mathrm{ml}$; streptomycin sulfate, $0.1 \mathrm{~g}$; rose bengal, $0.12 \mathrm{~g}$; and benomyl, $0.0025 \mathrm{~g}$ per $1000 \mathrm{ml}$ of

TABLE 1.-Sources of inoculum of Pythium spp. from sugarcane

\begin{tabular}{|c|c|c|c|c|}
\hline Species & Crop & Location & Year & Variety \\
\hline \multirow[t]{10}{*}{ P. aphanidermatum } & plant cane & Central Mercedita & 1975 & P.R. 66-2314 \\
\hline & 1st ratoon & Central Mercedita & 1975 & P.R. 61-632 \\
\hline & 1st ratoon & Central Mercedita & 1975 & P.R. 61-632 \\
\hline & ratoon cane & Central Mercedita & 1975 & P.R. 1152 \\
\hline & ratoon cane & Central Mercedita & 1975 & P.R. 64-1791 \\
\hline & plant cane & Central Mercedita & 1975 & P.R. $65-625$ \\
\hline & ratoon cane & Central Mercedita & 1975 & P.R. $65-625$ \\
\hline & ratoon cane & Central Mercedita & 1975 & P.R. 64-1791 \\
\hline & ratoon cane & Central Mercedita & 1975 & P.R. 1152 \\
\hline & ratoon cane & Central Mercedita & 1975 & M. 336 \\
\hline \multirow[t]{4}{*}{ P. deliense } & plant cane & Central Mercedita & 1975 & P.R. $66-2314$ \\
\hline & 1st ratoon & Central Mercedita & 1975 & P.R. $61-632$ \\
\hline & ratoon cane & Central Mercedita & 1975 & P.R. $65-625$ \\
\hline & ratoon cane & Central Mercedita & 1975 & M. 336 \\
\hline \multirow[t]{2}{*}{$P$ butleri } & ratoon cane & Central Mercedita & 1975 & P.R. $64-1791$ \\
\hline & ratoon cane & Central Mercedita & 1975 & P.R. $65-625$ \\
\hline \multirow[t]{2}{*}{ P. oligandrum } & plant cane & Central Mercedita & 1975 & P.R. $65-625$ \\
\hline & ratoon cane & Central Mercedita & 1975 & P.R. 1152 \\
\hline \multirow[t]{3}{*}{ P. periplocum } & ratoon cane & Central Mercedita & 1975 & M. 336 \\
\hline & 1st ratoon & Lajas & 1975 & B. 49119 \\
\hline & plant cane & Fortuna & 1974 & P.R. 980 \\
\hline \multirow[t]{2}{*}{ P. graminicola } & plant cane & Central Mercedita & 1974 & P.R. 980 \\
\hline & 1st ratoon & Central Mercedita & 1974 & P.R. 980 \\
\hline P. acanthicum & 1st ratoon & Fajardo & & P.R. 980 \\
\hline P. echinocarpum & 1st ratoon & Humacao & & P.R. 1059 \\
\hline
\end{tabular}

water was used to isolate the species of Pythium. Five representative Pythium isolates were sent to the Commonwealth Mycological Institute, Kew, Surrey, England for identification.

\section{PATHOGENICITY TESTS}

Pathogenicity tests with the Pythium isolates were conducted. Singleeyed seedpieces of sugarcane variety PR 1152 were obtained from a nursery planted with hot-water-treated stock which was planted in steamsterilized soil. Three weeks after germination, plants were transplanted 
to test tubes $(100 \mathrm{ml}$ ) containing liquid cultures (Czapex dox broth $35 \mathrm{~g}$ $+100 \mathrm{ml}$ water) of the various Pythium isolates. Ten tubes were used for each species of Pythium. Tubes containing only Czapek dox broth were used as controls.

\section{EFFECT ON STEM AND ROOT GROWTH}

The effect of various species of Pythium on root growth of sugarcane was tested in two replicated trials. PR 1152, a promising variety, was used in both trials. Koike's method (4) for testing the effect of Pythium on growth and root development of sugarcane was used. This consisted of inoculating roots of sugarcane with Pythium grown in a corn meal and sand medium. Seedpieces of sugarcane variety PR 1152 were derived from disease-free, hot water treated nursery stock $\left(50^{\circ} \mathrm{C}\right.$ for $\left.2 \mathrm{~h}\right)$. Two cuttings were planted in 25-cm clay pots, each containing $65 \mathrm{~cm}^{3}$ of a steam-sterilized 2:1 soil-cachaza mixture. The mixture used for these experiments was steam sterilized.

The first experiment was planted December 22, 1975, and harvested April 22, 1976. The following treatments were used: 1) soil infested with $P$. aphanidermatum; 2 ) soil infested with $P$. deliense; 3) soil infested with $P$. periplocum; and 4) uninfested controis. The pots were placed on two greenhouse benches with the control and Pythium-infested pots arranged in a complete randomized block design. The experiment was replicated eight times. The mean maximum temperatures were 31.2 and $17.2^{\circ} \mathrm{C}$, respectively with an average of $22.4^{\circ} \mathrm{C}$.

The second experiment was planted June 29, 1976, and harvested October 29, 1976. The treatments consisted of infesting the soil with the following species of Pythium: P. oligandrum, P. periplocum, P. graminicola, $P$. echinocarpum, $P$. aphanidermatum, $P$. butleri, $P$. deliense, and uninfested controls. The pots were arranged on greenhouse benches in a complete randomized block design with five replications. The mean maximum and minimum temperature were $35.2^{\circ}$ and $21.4^{\circ} \mathrm{C}$, respectively with an average of $28^{\circ} \mathrm{C}$.

\section{EFFECT OF Pythium SPP. ON GROWTH}

The variety PR 1085, which has shown a great deal of deterioration in ratoons under field conditions, was chosen for these studies. The experiment with a complete randomized design was initiated August 2, 1975 and harvested November 2, 1975. The treatments consisted of infesting the soil with species of Pythium: P. aphanidermatum, $P$. deliense, $P$. aphanidermatum, and $P$. deliense, and uninfested controls. The mean maximum and minimum temperature in the greenhouse during the perioc was $32.4^{\circ}$ and $18.2^{\circ} \mathrm{C}$, respectively, with a mean of $23.5^{\circ} \mathrm{C}$. 
INTERACTION BETWEen Pythium and RATOON STUNTING DISEASE

Single-eyed cuttings of PR 1152, derived from seedpieces previously inoculated with juice extracted from RSD-affected plants were planted February 12, 1975 in metal flats containing a steam sterilized soil and cachaza mixture. Cuttings derived from hot water treated seedpieces were planted as controls. The experiment, replicated five times in a complete randomized design, was harvested June 12, 1975. Included were four treatments with seedpieces from the following sources: RSD-affected nursery; hot water treated nursery; RSD-affected nursery, planted in soil
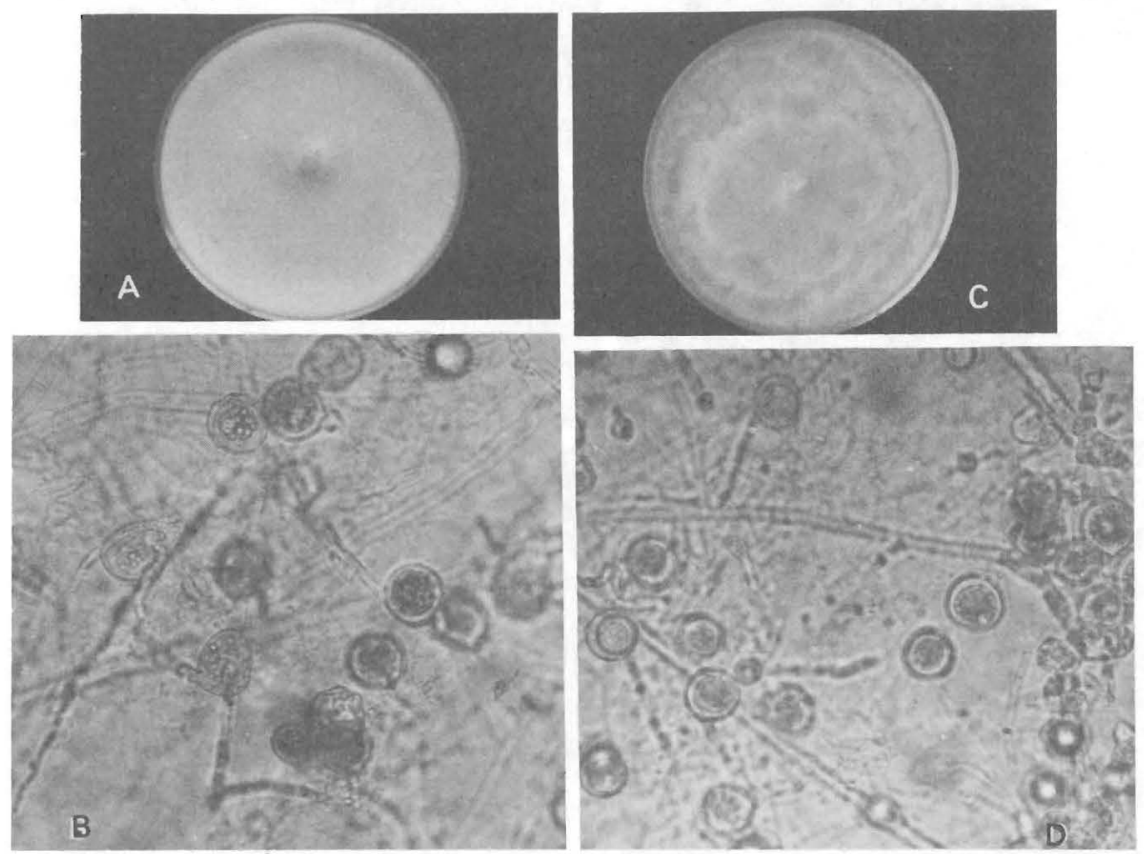

Fig. 1.-Cultural appearance and oogonia or oospores of the two most frequently isolated species of Pythium from sugarcane on the southern coast of Puerto Rico: A and B, $P$. aphanidermatum; $\mathrm{C}$ and $\mathrm{D}, P$. deliense.

infested with $P$. aphanidermatum; and hot water-treated nursery, planted in soil infested with $P$. aphanidermatum. The mean maximum and minimum temperature during the period was $23.8^{\circ}$ and $20.6^{\circ} \mathrm{C}$, respectively, with a mean of $28.4^{\circ} \mathrm{C}$.

In all the replicated greenhouse experiments, both fresh weights and dry weights of top and root growth were recorded. The dry weights were obtained by oven-drying the fresh stem and root at $110^{\circ} \mathrm{C}$ for $24 \mathrm{~h}$. Roots from all plants were examined for root rot symptoms. Pythium spp. were reisolated from root pieces showing lesions or discoloration. 


\section{RESULTS}

\section{ISOLATION AND IDENTIFICATION}

Pythium aphanidermatum, $P$. deliense, $P$. acanthicum, $P$. butleri, $P$. echinocarpum, $P$. oligandrum, $P$. graminicola and $P$. deliense were isolated from the Central Mercedita area on the southern coast of the Island. $P$. butleri, $P$. oligandrum and $P$. periplocum were isolated from
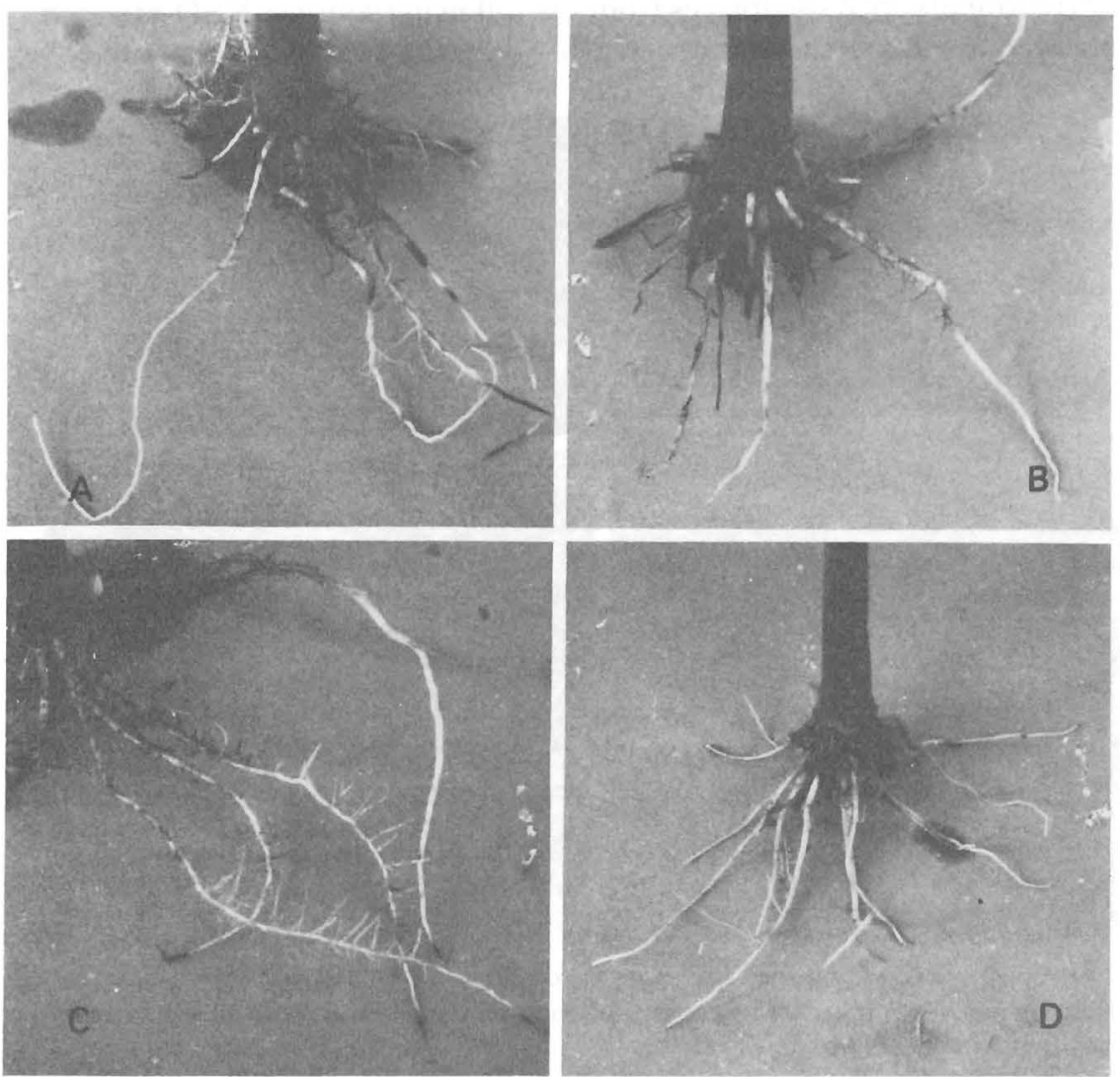

FIG. 2.-Lesions on roots of 6-week-old plants of variety PR 1152 growing in liquid cultures of four species of Pythium. A, P. graminicola; B, P. aphanidermatum; C, P. deliense; D, control-no Pythium.

roots of varieties PR 64-1791, PR 65-625 and M 336 from the same general area. P. graminicola, $P$. acanthicum and $P$. echinocarpum were isolated from roots of PR 980 and PR 1059 from Central Plata, Fajardo and Humacao (table 1).

Pythium aphanidermatum, $P$. deliense, $P$. butleri, $P$. acanthicum and P. echinocarpum were identified by the Commonwealth Mycological 
Institute, Kew, Surrey, England. P. oligandrum, P. periplocum and $P$. graminicola were identified by the author by comparison with the known Pythium cultures supplied by Dr. H. Koike (3). Figure 1 shows the cultural appearance and oogonia of the two most frequently isolated Pythium species (P. aphanidermatum and P. deliense).

\section{PATHOGENICITY TESTS}

The results from inoculation studies on sugarcane variety PR 1152 with $P$. aphanidermatum, $P$. deliense, $P$. acanthicum, $P$. butleri, $P$.

TABLE 2.-Effect of three species of Pythium on stem growth and root development of sugar cane variety $P R 1152$

\begin{tabular}{lll}
\hline \multirow{2}{*}{ Treatment } & \multicolumn{2}{c}{ Dry weight (grams) } \\
\cline { 2 - 3 } & Stem & Root \\
\hline Pythium aphanidermatum & $236^{1 *}$ & $43^{*}$ \\
Pythium deliense & $214^{*}$ & $46^{*}$ \\
Pythium periplocum & 321 & 68 \\
Control & 322 & 79 \\
\hline
\end{tabular}

' Average of 8 replications.

* Significantly different from the control at the $5 \%$ level.

TABLE 3.-Effect of Pythium spp. on stem and root growth of sugarcane variety PR 1152

\begin{tabular}{lcc}
\hline \multicolumn{1}{c}{ Treatment } & \multicolumn{2}{c}{ Dry weight (grams) } \\
\cline { 2 - 3 } & Stem & Root \\
\hline P. oligandrum & $72^{1}$ & 41 \\
P. periplocum & 70 & 41 \\
P. graminicola & $53^{2}$ & $31^{2}$ \\
P. echinocarpum & $52^{2}$ & $30^{2}$ \\
P. aphanidermatum & $53^{2}$ & $31^{2}$ \\
P. butleri & $52^{2}$ & $31^{2}$ \\
P. deliense & $60^{2}$ & $31^{2}$ \\
Control & 77 & 42 \\
\hline
\end{tabular}

${ }^{1}$ Average of 5 replications.

${ }^{2}$ Significantly different at the $1 \%$ level.

echinocarpum, $P$. graminicola, $P$. oligandrum and $P$. periplocum indicate that all the species mentioned above could infect roots of sugarcane variety PR 1152 and induce symptoms similar to those reported for Pythium root rot. The first lesions appeared 4 days after transplanting the healthy plants into a test tube containing the liquid cultures of the Pythium isolate (fig. 2). No such symptoms occurred in roots of control plants. 
EFFECT OF Pythium SPP. ON STEM AND ROOT GROWTH

Tables 2 and 3 indicate that dry weights of roots and stems of variety PR 1152 inoculated with $P$. aphanidermatum, $P$. deliense, $P$. graminicola, $P$. butleri, and $P$. echinocarpum were significantly reduced but not those inoculated with $P$. oligandrum and $P$. periplocum.

\section{EFFECT OF Pythium SPP. ON TOP AND ROOT GROWTH}

Table 4 shows that $P$. aphanidermatum alone significantly reduced dry weights of top and root growth of variety PR 1085. Reductions in dry

TABLE 4.-Effect of three Pythium species on stem growth and root development of sugarcane variety PR 1085

\begin{tabular}{llc}
\hline \multirow{2}{*}{ Treatment } & \multicolumn{2}{c}{ Dry weight (grams) } \\
\cline { 2 - 3 } & Stem & Root \\
\hline Pythium deliense & $33^{1.2}$ & $11^{2}$ \\
Pythium aphanidermatum & $31^{2}$ & $10^{2}$ \\
Pythium aphanidermatum & $29^{2}$ & $9^{2}$ \\
$\quad+$ Pythium deliense & & \\
Control & 47 & 16 \\
\hline
\end{tabular}

${ }^{1}$ Average of 7 replications.

${ }^{2}$ Significantly different from the control at the $1 \%$ probability level.

TABLe 5.-Interaction between Pythium aphanidermatum and ratoon stunting disease agent on sugarcane variety $P R 1152$

\begin{tabular}{lrc}
\hline \multirow{2}{*}{ Treatment } & \multicolumn{2}{c}{ Dry weight (grams) } \\
\cline { 2 - 3 } & \multicolumn{1}{c}{ Stem } & Root \\
\hline Hot water treated cane (control) & $104^{\prime} \mathrm{a}$ & $52^{2} \mathrm{a}$ \\
Hot water treated cane inoculated & $85 \mathrm{~b}$ & $41 \mathrm{~b}$ \\
$\quad$ with Pythium aphanidermatum & $66 \mathrm{c}$ & $37 \mathrm{c}$ \\
Ratoon stunt affected cane & 53 & $31 \mathrm{c}$ \\
Ratoon stunt affected cane inoculated & & \\
with Pythium aphanidermatum & & \\
\hline
\end{tabular}

${ }^{1}$ Average of 5 replications.

${ }^{2}$ Means followed by the same letter do not differ significantly at the $5 \%$ probability level.

weights of top and root growth by the combination of $P$. deliense, and $P$. aphanidermatum were similar to those caused by $P$. aphanidermatum alone.

\section{interaction between Pythium aphanidermatum and Ratoon STUNTING AGENT}

Table 5 shows that the reduction in dry weights of top growth by inoculation of sugarcane with both $P$. aphanidermatum and ratoon stunting disease agent was greater than that when inoculated by either 


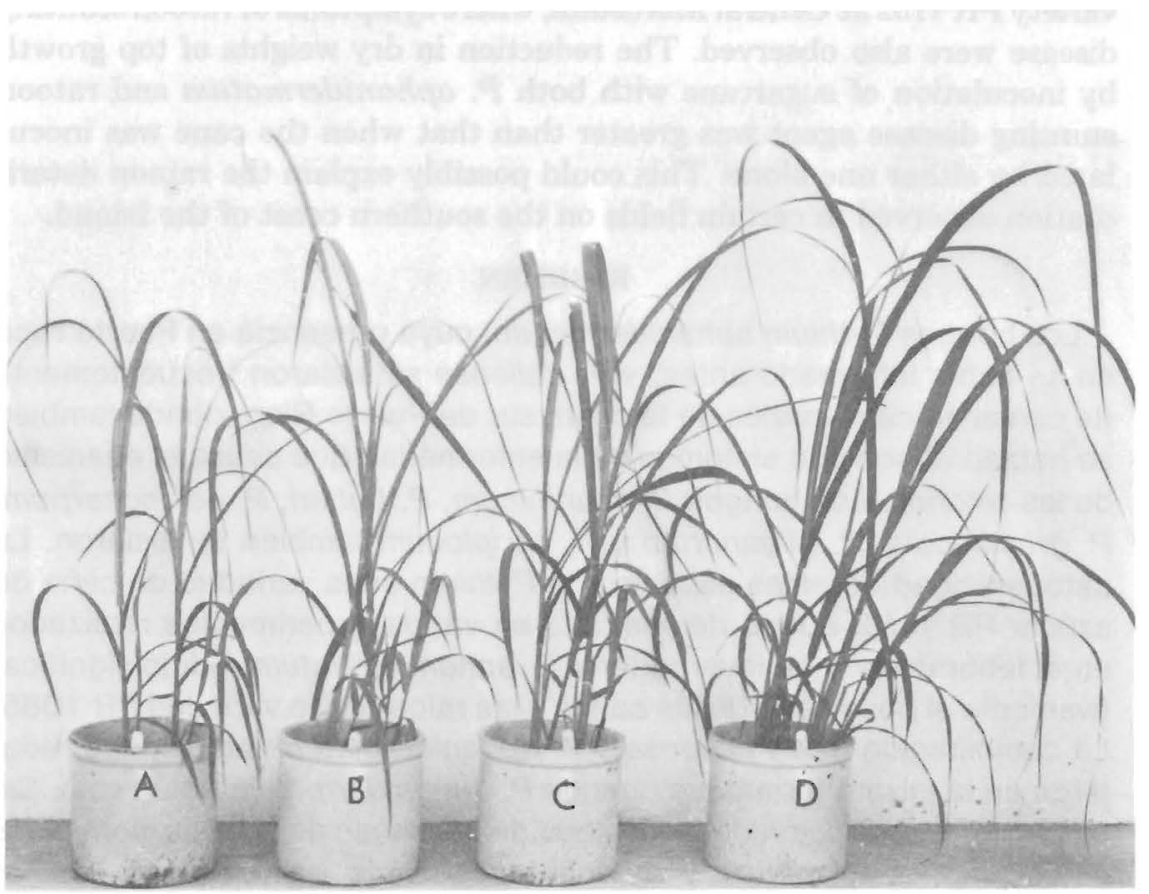

FIG. 3.-Growth differences between plants of variety of PR 1152 affected by Pythium aphanidermatum alone and those affected by a combination of Pythium and ratoon stunting disease agent. A, ratoon stunt affected canes inoculated with $P$. aphanidermatum; $\mathrm{B}$, ratoon stunt affected cane; C, hot water treated canes inoculated with $P$. aphanidermatum; D, hot water treated canes (control).

one alone. Figure 3 shows the differences in top growth between canes affected by ratoon stunting disease alone and those affected by the combination of Pythium and ratoon stunting disease.

\section{DISCUSSION}

The results obtained agree in general with the findings of Koike $(3,4$, 5), who reported that $P$. graminicola reduced significantly the dry weights of top and root growth of sugarcane. In addition, $P$. aphanidermatum, $P$. deliense, $P$. butleri, and $P$. echinocarpum were also demonstrated to reduce dry weights of top and root growth of sugarcane variety PR 1152 in Puerto Rico.

Pythium echinocarpum, $P$. acanthicum, and P. aphanidermatum had not been reported on sugarcane in Puerto Rico. The first two species were isolated from roots of varieties PR 1152 and PR 980, respectively, in the Fajardo and Humacao areas on the eastern coast of the Island. The third species and $P$. deliense were frequently isolated from roots of 
variety PR 1152 at Central Mercedita, where symptoms of ratoon stunting disease were also observed. The reduction in dry weights of top growth by inoculation of sugarcane with both $P$. aphanidermatum and ratoon stunting disease agent was greater than that when the cane was inoculated by either one alone. This could possibly explain the ratoon deterioration observed in certain fields on the southern coast of the Island.

\section{RESUMEN}

Los hongos Pythium aphanidermatum, cuya presencia en Puerto Rico no se había informado antes, y $P$. deliense se aislaron frecuentemente de cañas en cañaverales de la costa sur de Puerto Rico, donde también se habían observado síntomas de la enfermedad que causa el enanismo de los retoños. Los hongos $P$. acanthicum, $P$. butleri, $P$. echinocarpum, $P$. graminicola, $P$. oligandrum y $P$. periplocum también se aislaron. La patogenicidad de estas especies de Pythium en la variedad de caña de azúcar PR 1152 quedó demostrada en varios experimentos realizados en el laboratorio y en invernadero. $P$. aphanidermatum redujo significativamente el peso seco de las cañas y las raices de la variedad PR 1085. La combinación de $P$. deliense y $P$. aphanidermatum también los redujeron en la misma forma que cuando $P$. apahnidermatum actúa solo. Sin embargo, la reducción del peso seco de las cañas de plantas inoculadas con $P$. aphanidermatum y el agente causante del enanismo de los retoños fue más severa que en las plantas inoculadas con el uno o el otro separadamente.

\section{LITERATURE CITED}

1. Bourne, B. A. 1922. Researches on the root disease of sugarcane, Dep. Agri., Barbados.

2. Koike, H., 1969. Fungi associated with sugarcane roots and soils in Puerto Rico (Abst.). Phytopathology, 59 (10): 1348.

3. __, 1971. Individual and combined effects of Pythium tardicrescens and Pythium graminicola on sugarcane: A first report, Plant Dis. Rep. 55 (9): 766-770.

4. _- and Román, J., 1970. Pathogenicity of Pratylenchus brachyurus and Pythium graminicola on growth of sugarcane, Phytopathology, 61. (9): 1090-92.

5. Liu, L. J., 1977. Pathogenicity, biology, interaction with ratoon stunting causal agent and in vitro sensitivity to herbicides of several Pythium isolates from sugarcane in Puerto Rico, Proc. Am. Phytopathological Soc. 4: 179.

6. Matz, J., 1920. Investigations of root disease of sugarcane, J. Dep. Agri. P. R. 4: 28-47. 